\title{
EDUCATION METHOD AKHLAK IN SDIT UMMUL QURO
}

\author{
M. Agus Patoni' ${ }^{1}$ Wido Supraha ${ }^{2}$, Anung Al Hamat ${ }^{3}$ \\ ${ }^{1}$ Universitas Ibn Khaldun (UIKA) Bogor \\ ${ }^{2}$ Universitas Ibn Khaldun (UIKA) Bogor \\ ${ }^{3}$ Universitas Ibn Khaldun (UIKA) Bogor \\ agusfathoni05@gmail.com \\ suprahawido@gmail.com \\ anung.alhamat@gmail.com
}

\begin{abstract}
This research focuses on the background of morals decline in early childhood caused by lack of attention or supervision of parents and schools towards them. Morals in Islamic civilization is a fence that limits both at the same time the upright foundation upon which the glory of Islam. The basic values of Islam and morals are included in every rule of life, various kinds of differences and their development, both individually, as well as society, politics and economics. This research was formulated to describe the various methods of moral education that are applied at SDIT Ummul Quro. This research is a type of qualitative research with a field research approach, aims to explore various methods of moral education through primary and secondary literature relating to the object of research, then integrated with field research in an effort to produce products to be implemented in other institutions. This research resulted in the method of elementary school morals education at the institution, namely: (1) the exemplary method of an educator figure (2) the habituation method was more emphasized to students as recipient subjects (3) the reward and funishment method (reward and sanctions), in the form gift giving and sanctions.
\end{abstract}

Keywords: method, education, morals, Elementary School

\begin{abstract}
ABSTRAK
Penelitian ini berfokus pada latar belakang terjadinya kemerosotan akhlak pada anak usia dini disebabkan karena kurangnya perhatian atau pengawasan orang tua dan sekolah terhadap mereka. Akhlak dalam peradaban Islam merupakan pagar yang membatasi sekaligus dasar yang tegak yang di atasnya kejayaan Islam. Dasar nilai-nilai Islam dan akhlak masuk dalam setiap aturan kehidupan, berbagai macam perbedaan dan perkembangannya, baik secara individu, maupun masyarakat, politik maupun ekonomi. Penelitian ini dirumuskan untuk mendeskripsikan berbagai metode pendidikan akhlak yang diterapkan di SDIT Ummul Quro. Penelitian ini merupakan jenis penelitian kualitatif dengan pendekatan field research, bertujuan untuk menggali berbagai metode Pendidikan Akhlak melalui literatur primer maupun sekunder yang berkaitan dengan objek penelitian, kemudian diintegrasikan dengan penelitian lapangan dalam upaya untuk melahirkan produk untuk diimplementasikan pada lembaga lain. Penelitian ini menghasilkan metode pendidikan akhlak Sekolah Dasar pada lembaga tersebut yaitu: (1) metode keteladanan dari seorang figur pendidik (2) metode pembiasaan lebih banyak ditekankan kepada peserta didik sebagai subyek penerima (3) metode reward dan funishment (pahala dan sangsi), berupa pemberian hadiah dan sangsi.
\end{abstract}

Kata kunci: metode, pendidikan, akhlak, sekolah dasar 


\section{A. INTRODUCTION}

Throughout the history of mankind, the issue of morals has always been a problem, because basically the discussion of morals has always been related to the problem of human behavior and has become the main problem of mankind, especially in the context of the formation of civilization. Human behavior, directly or indirectly, is still a benchmark for knowing human actions or attitudes. Naturally, the issue of morality is always associated with the problems of society, because morals are a symbol for the civilization of a nation. (Munirah, 2017).

The main mission sent by Rasulullah SAW is to perfect noble morals, "in fact I was sent to perfect noble morals". As explained in His words (Surah Ibrahim / 14: 1) "Alif Lam Ra (this is) the Book that We sent down to you (Muhammad) so that you can bring people out of darkness into bright light with the permission of God". According to the Qurais Shihab, "bringing people out of darkness into light", means removing all human beings from various darkness, regardless of shape and type, including morals that are despicable to humans. (Mustopa, 2014).

Moral education is very important to be given to early childhood, because with good morals it can protect our children from things that are prohibited by religion, so that our children can be protected from hellfire. The family is the main and first environment for the child's development process as well as the foundation of the child's personality. If a child is raised with good moral education from his parents, he will grow up to become a child with noble character, and vice versa. After getting education from their families, the children are then introduced to the school environment. In looking for educational institutions for their children, parents not only pay attention to education in terms of academics and cognition, but moral or moral education is also very important because good moral education can become the basis for children to behave well in the future.

In Indonesia, currently, the problem is the decline in community morals, which is a concern. Cultural globalization is often considered to be one of the causes of this moral decline. Indeed, advances in philosophy, science and technology have resulted in an increasingly advanced culture, but this increasingly globalized culture has a profound impact on the moral aspects of humans themselves, including early childhood. Islamic education concept will make children have a filter in their social behavior, children will be able to do 
good and avoid bad things. Therefore, the formation of good morals begins with the provision of Islamic teaching as early as possible for children.

Morals education can be provided through several methods, including exemplary methods, habituation and so on. Exemplary is an educational method by providing a good example to students, both in speech and in deed. (Khomsiyatin 2017).

By providing moral education to elementary school children, it is hoped that it can change children's behavior, so that students when they are adults are more responsible and respectful of others and are able to face the challenges of the times that are fast and changing. This is where the importance of moral values that function as a medium for transformation of Indonesian people to be better, have advantages and intelligence in various fields, both emotional intelligence, social intelligence, spiritual intelligence, kinesthetic intelligence, logical intelligence, spiritual intelligence, logical intelligence, musical intelligence, and linguistics. (Yusra, 2015).

To cultivate and develop noble morals, educational institutions are needed that make moral development a central issue, and its existence is one of the means to build the good of individuals, society and human civilization. And keep in mind that the development of moral education is well designed by taking into account the opportunities and challenges that arise (Daulay, 2004: 216). (Yusra, 2015).

SDIT Ummul Quro is an educational institution or institution located in Bogor Regency which aspires to the formation of a scholarly generation, the curriculum refers to a reference where teachers are responsible and have a high commitment in conveying knowledge to school students and applying cultivating morals through the process of daily habituation accompanied by ustad / utadzah wholeheartedly so that they have good character.

\section{B. LITERATURE REVIEW}

\section{Moral Education}

The word is taken from the word education and morals. Education in Law no. 20 of 2003 concerning SISDIKNAS, which is a conscious and planned effort to create a learning atmosphere and learning process so that students actively develop their potential to have religious spiritual strength, self-control, personality, intelligence, noble character, and skills needed by themselves, society, nation and state.

Ibn Maskawih defines morals, which is a mental attitude or mental state that encourages someone to act without thinking and consideration. Meanwhile, human 
behavior is divided into two elements, namely instinctual character elements and elements through habit and training (Amin, 1996).

Moral education is the glue that knits all types of education, such as reason education, ethics education, moral education and so on. All types of education must comply with moral principles.

Abdullah Nashih Ulwan defines moral education (moral) as a moral basis and the virtue of attitude and character (character) that a child must have and become a habit from when he was a beginner until he became a mukallaf, that is, ready to navigate the oceans of life.

Moral education is a conscious effort to guide and direct a person's will in order to achieve good behavior and is directed to make it a habit. (Khomsiyatin, 2017).

One thing that is emphasized in Islam is that moral education is compulsory starting at an early age because childhood is the most conducive period for instilling good habits. The purpose of moral education is the habituation of a child to have good character and to have a noble character so that it becomes his permanent nature and character that always accompanies him. Included in moral education is keeping away from despicable morals and bad temperament. A child will grow in accordance with the habits instilled by the educator in him.

Including something that is really needed by young children is attention to moral matters. Because, he will grow in accordance with what his educators used to do in his childhood.

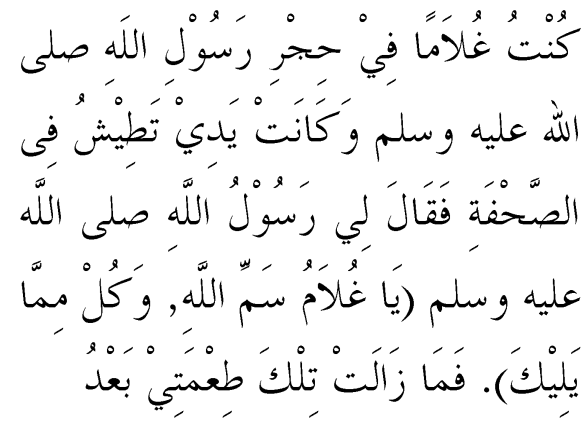

I was a child under the care of the Prophet sallallaahu alaihi wasallam, and while eating with my hands moving there and here, the Prophet sallallaahu alaihi wasallam, said to me, 'O young man, read the bismillah and eat with your right hand and eat. from what is close to you, 'So since then that's how I always eat (Narrated by Bukhari and Ahmad). (Bafadhol 2017).

\section{Integrated Islamic Elementary School}

Integrated Islamic Schools are newcomers to the education scene in Indonesia so they have flexible options for the curriculum that is applied. However, there are certain considerations that are used when choosing the curriculum to be applied. These considerations, for example, are pragmatic considerations. Because they are in the territory of the Unitary State of the Republic of Indonesia (NKRI), they have to 
choose between the curriculum of the Ministry of Education and Culture and the curriculum of the Ministry of Religion. This consideration is carried out in order to provide plus value to the users of these educational institutions (Suyatno 2013)

The world of school education is a very important means of developing children's abilities, be it schools based on religious values (Islamic schools) or public / private schools. The definition of Islamic education in terminology according to Omar Muhammad al-Toumi al-Syaibani "Islamic education is the process of changing individual behavior in personal life, society and the surrounding environment, by teaching as a basic activity in society", the philosophy of Islamic education (1979: 399) .

The Indonesian Integrated Islamic School Network (JSIT) argues that the Integrated Islamic School is a school that balances religious education and general education, but in terms of quality it is actually not inferior to existing public schools. Because integrated Islamic schools try to educate and equip generations with religious and worldly knowledge, by increasing learning achievement and the learning process, which in essence learning achievement is the end result of the learning process.
In addition, an article in February 18 2012 states that the meaning of Islamic education or (Integrated Islamic School) is a school that carries out a process that aims to create human beings who are complete, faithful and devoted to God and able to realize their existence as the caliph of Allah on earth. , which is based on the teachings of the Qur'an and Sunnah, the goal in this context is the creation of human beings after the education process ends. (Agustina n.d).

The psychological condition has a big influence on teaching and learning activities, especially for vulnerable school age children. The following hadith explains that the nature that a person carries from birth has a very large influence on the environment, especially in the family environment. As the saheeh hadith HR Bukhari and Muslim which means:

Meaning: "Every child who is born is in a state of nature. So the condition of his parents that made his son Jewish, Christian and Magi ". (Narrated by Bukhari and Muslim).

As mentioned above, that the nature brought by large children affects the environment, especially from the family environment. In this regard, the basic potential possessed by children must be developed by making efforts in the form of education (influencing from outside) that can be done by parents, teachers or people 
around the child. A bad psychological condition (Hawi 2015), one of which is caused by disturbances or environmental conditions. Psychological problems are problems experienced by the full day school system.

SDIT uses the full day school system or what is called a full day school. It can also be interpreted as "an all-day learning system" or longer school education. The Full Day School system also means learning time until the afternoon. In essence, the concept of Full Day School in a true sense is characterized by a longer study time than conventional schools and the interaction between students and the influence of their teachers is more intensive.

The full day school system within the scope of primary schools is one of the educational institutions that prepares superior humans from an early age, because at the age of 6-12 years it is a development of all self-potential for children, both emotionally, intellectually and morally. (Hawi, 2015).

\section{Morals Education Methods}

Forming children with noble character or character is not only done with words or commands, but must be exemplary from parents or educators. Education and psychology experts say that children will imitate what their parents or educators do. The methods of moral education include:

a. Education by example

Modeling is a very effective Islamic education method applied by a teacher in the educational process. Because with exemplary education will affect individuals on habits, behavior and attitudes. In the AlQur'an the word exemplary is projected with the word uswah which is then given the trait behind it such as hasanah which means good. So there is the expression uswatun hasanah which means a good role model. The words of uswah in the Al-Qur'an are repeated three times by taking samples from the prophets, namely the Prophet Muhammad, the Prophet Ibrahim, and people who believe firmly in Allah.

Children are creatures who enjoy imitating. His parents are his figures and idols. If they see the good habits of their father and mother, they will quickly imitate them. Parents who have bad behavior will be imitated by their behavior. Children also find it easiest to follow the words that come out of their parents' mouths. Rasulullah Saw sometimes gave 
direct advice to children. (Mustofa, 2015).

Exemplary from parents and teachers is something that children need in developing their personality. The importance of exemplary parents and teachers is based on the tendency of children to imitate and imitate the actions and behavior of adults. In addition to imitation, imparting values and forming attitudes must be practiced repeatedly or habitually. (Sitompul, 2016).

Exemplary education is an influential and proven method to prepare and shape children's moral, spiritual and social ethos. This is according to 'Ulwan (1992, p. 2) because educators are "the best figures in the eyes of children, whose politeness, behavior, whether their students are aware or not imitated". (Manan, 2017).

Every child has their own nature (potential) that can be good, but no matter how big the potential is, the child will not just follow the principles of goodness as long as he has not seen the educator show good and noble character and set a good example.
It is very easy for educators to provide a lesson for children, but it is very easy for children to follow it when they see the person giving the lesson not practicing what they teach.

Therefore, Allah has sent an Apostle to preach to the people, and an Apostle must have a perfect character, a clean soul, noble character and high intellect. So that people can refer to it, obey, learn from it, and imitate it in glory and moral elevation. This is found in AlQur'ān Surah Al-Ahzab] 33 [verse 21:

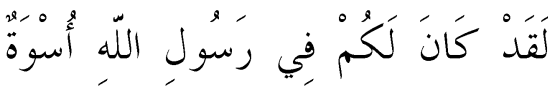

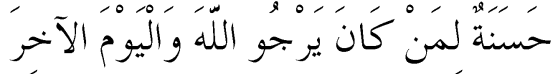

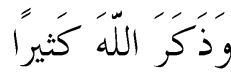

Indeed, the Prophet (himself) was a good role model for you (namely) for those who hope for (the mercy) of Allah and (the arrival of) the Day of Judgment and He chants Allah a lot. (Ayuni, 2016).

The verse is clear that the life of the Prophet Muhammad is a perfect example for the life of mankind. However, full grace (gain) is only for those whose love for God is so great, whose hopes and aspirations are centered solely on the Almighty. 
Only on Him hang hopes for the happiness of the Hereafter and really long for Him in all the pores of the body capable of imitating the life of the Prophet. (Mustofa, 2019).

In the context of the Prophet Ibrahim's story, the example of Prophet Abraham appears in his personal figure as a figure of a child, father and servant of Allah. As a child, Prophet Ibrahim had great respect and love for his parents, this respect was seen when he never interfered with his father's "profession" as a sculptor or statue maker. Only, the problem is why the statues made by humans are made into worship (idols) and are considered as God. Love for parents can be seen when Prophet Ibrahim always prayed to ask forgiveness for his father because he was a good person.

The figure of a father appears in the love and longing of Prophet Ibrahim for his son, Prophet Ismail. Even though Prophet Ismail was far away (in Mecca), Prophet Ibrahim did not lose his love for Prophet Ismail. In fact, when Prophet Ismail had a family, his care and affection for
Prophet Ismail always had a place in his heart.

As a figure of a servant of Allah, it can be seen from the obedience in carrying out Allah's orders, persistence in the struggle to uphold the religion of Tauhid, as well as patience in facing all the obstacles, challenges and threats it faces. (Hasan, 2017).

b. Education with customs

Habit is a condition in which a person applies behaviors that have never or rarely been carried out become frequently carried out so that in the end it becomes a habit. (Khosiyatin, 2017).

Hafsah Sitompul also revealed the same thing that habituation is one of the most important educational tools, especially for young children, because children are not aware of the good and bad in religion and moral values. Children's attention always changes from one object to another according to their life and social experiences. When he pays attention to new things then he forgets others, because of that habituation must be done in children, so that they form good habits for him. This can be done by 
getting him used to helping others, getting used to saying basmalah, hamdalah, and learning and working in his life in a disciplined manner. (Sitompul, 2016).

If the example relates to how to get rid of bad habits in a gradual manner as mentioned above, the Al-Qur'ān also uses it in a gradual manner in creating good habits in a person. In this connection there are instructions from the Prophet who instructed parents to order their children to perform the prayers at the age of seven, then it was permissible to beat him if the child was up to 10 years of age who had not yet performed the prayers. The words of the Prophet Muhammad

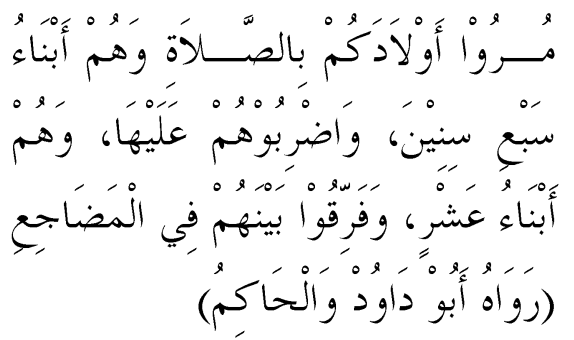

"Tell your child to pray when he is 7 years old, and when he is 10 years old, leave the prayer, then beat him. And separate the beds (between boys and girls). "(H.R.

\section{Abu Daud, No. 495)}

It also includes effort in a theoretical dimension. The practical aspect is to teach children about the law of prayer, the number of cycles, how to do it, then get used to doing it in congregation in the mosque, so that prayer is an inseparable habit.

It has been stipulated in Islamic law that children from birth have been created and given pure monotheism, a righteous religion, and faith in Allah. As Allah SWT says in AlQur'an Surat Ar-Ruum [30] verse 30:

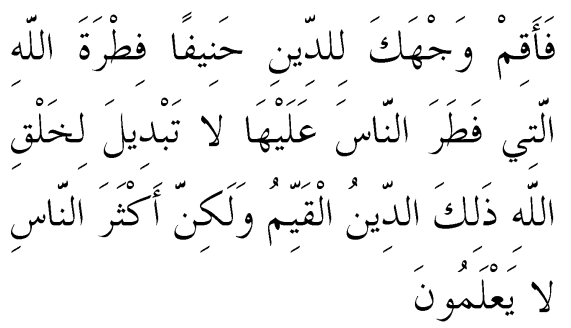

Then turn your face Straight to the religion of Allah; (stay on) the nature of Allah who created humans according to that nature. there is no change in the nature of Allah. (That is) righteous religion; but most humans don't know.

This verse is an order to strengthen the views (principles of life) and mengistiqomahkan everything above the religion that Allah revealed to mankind, in the form of the purity of the teachings of Abraham a.s which Allah guided you to him and Allah perfected that religion for you perfectly. In addition, you should be consistent with the straight fitrah that Allah insults His creatures to recognize 
and affirm Him who is not there is God (Haq) but Him: 371). (A'yuni, 2016).

It has been stipulated in Islamic law that every child from birth has been created in a state of pure monotheism, upright religion, and faith in Allah. From here we can begin to do habituation and discipline to take its role, in the growth of children and strengthen pure monotheism, noble morals, great souls and upright sharia ethics. Therefore, it can be ascertained that a child will become a righteous person if two factors support it, namely the noble Islamic education factor and the conducive environmental factor. (Abdullah Nashih 'Ulwan, Education in Islam: $625)$.

Regarding this factor of Islamic education, the Prophet has explained it in a hadith. Which means, "No gift that a father gives to his child is better than a good education." (H.R. At-Tirmidhi).

Meanwhile, the environmental factors that are conducive are also explained in a hadith which means "every baby who is born in a state of fitrah, then both parents make Jews,
Christians, or Magi" (Narrated by Bukhori). It can be understood that if a child has parents who are righteous and righteous, they will always teach the principles of faith and Islam so that the child will grow up with a strong faith and Islamic creed. (Ayuni, 2016).

In the hadith statement above, it is clear that parents and the environment play an important role in developing the potential or nature of a child, and the environment that the child first recognizes is the family environment, so this environment must provide education to the child. Given the importance of education, the role of parents and teachers in educational institutions greatly affects all children's potential, one of which is children's creativity. By providing proper parenting, it will help children to develop their creative potentials. (Nurjanah, 2017).

More especially habituation must be given early. Habits carried out early on will bring hobbies and habits so that they become an inseparable part of the Muslim personality. AlGhazali said that: 
"Children are the trust of their parents, a clean heart is a precious and pure gem, which is empty of every text and picture. This heart is ready to accept writing and tends to everything it wants. Therefore, if he is accustomed to doing good, then growing on that goodness, he will be happy in the world and in the hereafter, his parents will also be rewarded together.

Parents should be aware of the threat of globalization which will erode the child's personality. According to Zakiah Daradjat, that one of the moral crises that occurs in society is due to weak supervision so that the response to religion is lacking. The moral crisis indicates the quality of religious education which should provide spiritual value but it does not have strength because of lack of awareness in religion. (Khoerunisa dan Hidayat, 2017).

c. Education with advice

Abdullah Nashih Ulwan revealed that this method is an educational method that is quite successful in forming a child's faith and preparing it formally, emotionally, and socially, is to educate children with advice and to give them advice. (Ulwan, 2007).

In addition, the method of advice education is also effective in shaping children's faith, character, social, mental and social. This is because advice has a huge influence in making children understand the nature of things and giving them awareness of Islamic principles. (A’yuni, 2016).

According to the Al-Qur'an, the method of advice is only given to those who violate the rules and advice. The goal is to raise awareness of the person being advised to be converted to implement the legal provisions or teachings imposed on him. (Asy'ari, 2014).

One example of the method of advice that Allah describes in the story of Lukman in Surat Luqman (31) verse 13:

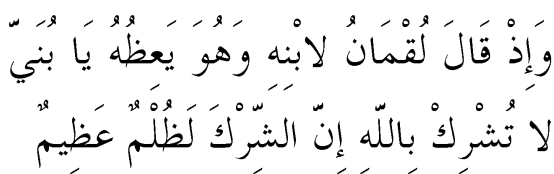
and (remember) when Luqman said to his son, when he taught him: "O my son, do not associate with Allah, Verily associating partners with (Allah) is truly a great tyranny".

According to Ibn Kathir, this verse reports about Lukman's will to his 
son, namely Lukman bin Unaqabin

Sadun, while the name of his son is Tsaran, according to one opinion narrated by as Shuhaily. Allah has pronounced it with the best possible title and gave him wisdom. He gave a will to his son who was the one he most loved and loved, and this is the essence of the gift of a child. For this reason, first of all he gave a testament to always worship Allah $T a^{\prime} a l a$, the One who has no partner for Him. Then he also warned that actually associating partners with Allah is a very big tyranny (Ibn Kathir: 400-402).

Parents really want their children to be masters of kindness, and parents may only be role models and counselors for their children. Like Luqman forbids his son to do shirk, and he gives the reason for the prohibition, that polytheism is a very big tyranny. (Sayyid Qutub, Tafsir fi Zhilalil Qur'an: 174).

In the advice of a father to his child, the Koran describes the relationship between the two parents and their children. $\mathrm{He}$ describes the relationship in an image of love and tenderness. This tenderness will arise when a family has a very strong faith and faith in Allah Ta'ala.

(A'yuni, 2016).

d. Education by payying attention

The purpose of education with attention is to always pay full attention and follow the development of the child's faith and moral aspects, monitor and pay attention to mental and social readiness, in addition to always asking questions about the situation of physical education and scientific abilities. (Ulwan, 2007).

Besides that, it also follows the development of children and monitors them in the formation of their faith, morals, mental, and social, as well as their physical and intellectual development. Therefore, this method is a very powerful method for forming a balanced human being, namely: 1). Able to give all their rights according to their respective portions, 2) able to carry out all the responsibilities they must bear, 3) able to carry out all their obligations, 4) able to build a solid foundation of faith.

Below are some texts about the obligation to pay attention and carry out supervision as mentioned in the 
punishment may be carried out if verse 6:

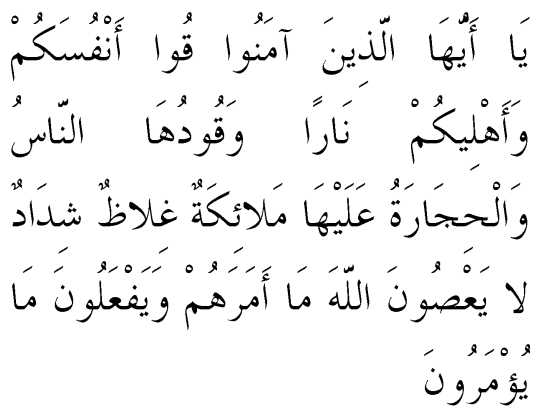

O you who believe, protect yourselves and your families from the fires of hell, whose fuel is men and stones; the keeper of the angels who were harsh, harsh, and did not disobey Allah against what He commanded them and always did what was ordered.

The point of this verse is that Allah commands believers to guard themselves from the fires of hell whose fuel consists of humans and stones, by obeying and obeying Allah's commands. They were also ordered to teach their families to obey and obey Allah's commands to save them from hellfire. Family is a mandate whose welfare must be maintained both physically and spiritually. Among the ways to save yourself from hell fire is to offer prayers and be patient. (Fakhruroji 2018).

\section{e. Education by giving punishment}

Punishment is an unpleasant repressive educational tool, reprimands and warnings have not been able to prevent students from committing violations, then in this case a punishment is given to students. Punishment is also a reward for bad deeds or violations that disrupt the course of the educational process in learning. With the application of the punishment, it is hoped that students will not repeat it again, and there will be awareness or regret so that they do not repeat their mistakes again in the future. (Nurmisdaramayani 2017).

This method of punishment is used in Islamic education as a means to improve the behavior of humans who commit violations and in a difficult level to be advised while the reward is given as a reward or appreciation to people who do good or obey or achieve good. (Asy'ari, 2014).

Islamic Sharia, which is straight and just, and its universal principles, really have a role in protecting primary needs that cannot be separated from human life. In this case, the mujtahid imams and ulama ushul fiqh underlined it in five cases. 
They named it adh-dharuriyyat alkhams (five musts) or kulliyyat alkhmas, namely guarding religion, guarding the soul, guarding honor, guarding reason and guarding property. They said, "in fact everything that is conveyed in Islamic law, in the form of law, principles and sharia, all of them aim to safeguard and maintain these five imperatives." (Ulwan, 2007).

An example that Islam requires punitive education in the form of hudud, and ta'zir is to realize a life that is calm, full of peace, security and tranquility. Therefore, there is no tyranny, oppression of the strong against the weak, the rich do not act arbitrarily against the poor. Everything is the same in front of the truth, there is no virtue for Arabs over non-Arabs, not for whites over blacks, except with piety. (Ulwan 2007). As Allah S.W.T. says in AlQur'an Surat Al-Baqarah [2] verse 179:

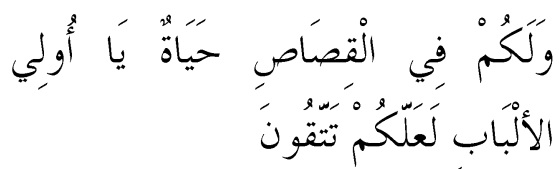

And in that qishaash there is (guarantee of survival) life for you, $O$ people who understand, so that you may fear.
In the field of education Al-Ghazali emphasized that educators should not give punishment unless they are forced to. That too is not allowed in a harsh way, but by advising it individually and at the same time investigating and looking for the reasons why students have done what is not appropriate to do. (Nurmisdaramayani 2017).

\section{METHODS}

This type of research used in this writing is a type of qualitative research with a field research approach that is oriented to describe the method of moral education in Ummul Quro SDIT, which then the results will be applied to other institutions.

Field research can also be considered as a broad approach to qualitative research or as a method for gathering qualitative data. The important idea is that the researcher goes to the field to make observations about a phenomenon in a natural or in situ state. (Lexy 2017).

This study uses data collection methods in the form of interviews, direct observation (observation), and document analysis related to the moral education method at SDIT Ummul Quro including the formulation of instruments that must be supported by a good communication style in conducting interviews with the intended person, the availability of documentation 
tools. sufficient to record the interview process, and documentation. In addition, the data collection in this study comes from field notes by referring to literature studies in the form of literature, so that data processing can be carried out thoroughly and is able to strengthen the authenticity of the research results.

In this study, the research instrument or tool is the researcher himself (human instrument) whose function is to determine the focus of research, select informants as data sources, collect data, assess data quality, analyze data, interpret data and draw conclusions on findings. (Sugiyono 2018).

\section{DISCUSSION RESULT}

Ummul Quro is one of the best elementary schools in Bogor. Many achievements have been made by these institutions. This is inseparable from the learning process carried out including the strengthening of the eight character principles, namely: manners, clean and tidy, praying with awareness, birrul walidain, discipline, honesty, spirit of recitation, memorizing the Qur'an and learners.

As a school that uses the Full Day School system, where learning activities, play activities, and interactions between students and student and teacher interactions occur during school hours, there needs to be monitoring of good habits, which are carried out by students.

At SDIT Ummul Quro the moral education methods applied are:

\section{Habituation Method}

The habits at SDIT Ummul Quro are known as school culture, the results of engineering elements in the school are then agreed to become habits. In general, the scope that is monitored and the main areas of school culture at SDIT Ummul Quro are: 1) Worship, 2) Orderliness, 3) Tidiness and Cleanliness, 4) Social Behavior, 5) Eating and Drinking, 6) Mechanisms for order, including : going to the prayer place / mosque, leaving the classroom, asking questions and in answering questions and finding items, and 7) Logical Consequences. This scope is applied in the activities implemented by SDIT Ummul Quro both in daily, weekly and monthly activities.

The habits carried out by students every morning at SDIT Ummul Quro are morning greetings (greeting early in the morning), this is intended so that they respect their elders, always say greetings, greet each other, line up neatly before entering class. Before starting to learn to pray with khusyu, and continue with recitations, 
When the break arrives, students immediately queue to go to the bathroom to get ablution water to perform the dhuha prayer in class for the afterlife and in the mosque for ikhwan, then eat the snacks that they bring from their respective homes starting and ending with praying. Towards the dzuhur prayer, students queue orderly to take the lunch that is already available in front of the class. They enjoy lunch together that begins and ends with prayer, eating in an orderly manner and not leaving any food. After eating, they use their spare time to visit the library or play together. Then after the end of the break, they returned to the class on time to participate in the next learning activity.

In recitation (reading Al-Qur'an) it is expected that every day according to the specified target ( 2 pages / day), while for tahfidz (memorizing Al-Qur'an) students are expected to memorize Al-Qur'an Juz 30 and $1 / 4$ juz 29 , and is able to translate lafdziah 16 short letters.

To further forgive the deepening of students' morals at SD IT Ummul Quro, there are also habituation and coaching programs that must be followed by students, namely: a) Deepening of Islam, b) Keputrian (especially for older children), c) Special Skills (Grades 1 and 2, d) Like to read, e) Like to save, f) Market day (grade
5), g) two weeks one khatam (grade 6), h) Training leadership, i) Persada, j) Mukhoyyam Qur'an, k) Islamic boarding schools Qur'an, 1) daily recitation / Murojaah, m) prayer guidance.

\section{Exemplary Method}

For educators or stake holders at SDIT Ummul Quro to be role models for students in monitoring these activities. Apart from that, they are also expected to always look neat, polite, and always wear syar'i clothes (according to Islamic law), and are obliged to take part in mentoring activities (Islamic studies) for work assessment performance.

In every lesson, educators always advise students to respect their parents (birrul walidain) and love the young, and to always pray in congregation.

\section{Reward and funishment Method}

Regarding rewards, Ummul Quro always gives prizes to students who excel, in the form of material and pleasing words such as subhanallah, thank God. Whereas in funishment (punishment) always gives educational warnings with the following stages:

a. The first stage calls students who violate school rules and then advises them with wise and educational words

b. The second stage involves involving parents in deliberation, 
c. The third stage is that the school will impose a suspension for students and their parents. Parents are expected to take time off work and have the obligation to monitor their children during the suspension period.

If you look at the program of activities carried out at SDIT Ummul Quro mentioned above, there are various methods of moral education that have been implemented, such as methods of habituation, exemplary, and reward and funishment.

The fostering of religious education and noble character for students needed in schools needs to prioritize the habituation and culture of religious experience and noble morals. The activity of habituating religious experiences in schools that has been developing has only been limited in the form of reading religious scriptures and the implementation of religious worship such as compulsory prayer in congregation at school. The culture of noble morals is prioritized in the context of student interaction by applying the values of politeness, smile, greetings, greetings and courtesy. For the purpose of habituation and civilization of religious education and noble morals, it turns out that support for the provision of religious facilities and infrastructure is the next option.

\section{Supporting factors and obstacles to the Implementation of Moral Development at SDIT Ummul Quro}

The connection with the supporting factors in the implementation of moral development at SDIT Ummul Quro, namely:

a. Parents, as the primary and first educators for their children, because it is from them that the first children receive education. Thus the first form of education is found in family life.

b. Teachers are professional educators, therefore implicitly they have volunteered themselves to accept and assume some of the educational responsibilities that are borne by parents. The teacher is a person who should be digested and emulated in addition to being a transmitter of knowledge (knowledge) to students as well as a party that has a significant influence on the formation (ethics) of students.

c. Learners

As an object, students receive lessons, guidance and various tasks and orders from the teacher / school and as a subject, they determine themselves according to their 
potential in order to achieve learning outcomes.

In connection with the barrier to the culture of SDIT Ummul Quro, in general every institution must socialize the rules, both for teachers and students. However, it cannot be denied that there are always violations committed by both teachers and students, as well as at SDIT Ummul Quro there are several things that hinder the realization of good discipline, because there are still some teachers and students who have not obeyed them as in the aspect of exemplary. There are teachers who have not participated in carrying out congregational prayers and are disciplined in time in the learning process.

The $4 \mathrm{~S}$ culture (smile, greetings, greetings, politeness) at SDIT Ummul Quro has been implemented, but in terms of practice there are still some teachers who have not implemented it optimally, such as in terms of greeting and greeting as a public, teacher figures have not set an example for their students. This was proven when there were still teachers who had not greeted and greeted their students during recess.

Every day in the process of growing and developing a child gets a lot of external influences. This influence can come from the immediate environment (parents, family) or from a distant environment (neighbors, school, community or social media). The influence on children can be something good or bad. Unfortunately, the bad effects are mostly received in terms of quantity and quality by children lately. This is because bad influences seem easier or more pleasant.

If you look at the discourse above, there are things that are less relevant to the phenomena that occur at SDIT Ummul Quro in relation to the bad effects of the school environment, as there are still Ummul Quro SDIT students who outside their learning mix with their seniors (SMK) so that it has a bad impact. against the child. This is evidenced by imitating negative habits that do not reflect the noble morals practiced by their seniors.

Seeing the phenomenon that occurs at SDIT Ummul Quro, there are still activities in terms of extracting and manifesting cultural-based noble moral values that have not been maximally implemented.

\section{Fill in the results of the discussion}

In building morals, a special strategy is needed so that the moral development of students can be successful. Exemplary and habituation in education are needed. Because psychologically, students imitate 
more behavior or figures that they idolize, including their teachers. Habit is equally important in learning activities. This is because any knowledge or behavior obtained by habituation will be very difficult to change and will eliminate it, so this method is very useful in educating children. (Manan 2017)

The implementation of extracting and manifesting noble moral values based on school culture is carried out by creating a school climate and environment that supports the exploration and realization of noble moral values. In this approach, what is very important is the involvement of all education systems, structures and actors in schools. This includes school governance, curriculum design, and school rules and regulations. Noble moral values that are prioritized and prioritized must be reflected in a positive school atmosphere that has farreaching dimensions and actively enriches the lives of students.

In order to assist adolescents (students) in strengthening or strengthening their faith and piety (according to Syamsu Yusuf), schools should make the following efforts:

a. Leaders (school principals and their representatives), teachers and other school personnel must equally have a concern for religious education programs or the cultivation of religious values in schools, either through (a) teaching and learning in class, (b) guidance (the meaning of the wisdom of living in religion / worship, giving encouragement, and giving examples / role models in speaking, behaving, dressing, or performing worship); and c) habituation in practicing religious values.

b. Religious teachers should have a solid personality (akhlakul karimah), professional understanding and skills, and the ability to package learning materials, so that religious subjects become interesting and meaningful for children.

c. Teachers insert religious values into the subjects they teach, so that students have a positive appreciation of religious values.

d. Schools provide religious facilities (mosques) as adequate spiritual laboratories, as well as to fully function them.

e. Organizing extracurricular spiritual activities, Islamic boarding schools, religious lectures, or regular religious discussions. 
f. Cooperating with parents of students in guiding student faith and piety.

In the midst of a modern era due to globalization, there are more and more things that hinder the implementation of moral education development. Therefore, efforts to overcome the obstacles found in SDIT Ummul Quro need full attention from various parties (family, school and community). The school must further increase supervision (controlling) of the activities of students while in the school and further increase the mentoring activities (Islamic studies) which are intended for teachers or supervisors at the school.

\section{E. CONCLUSION}

Among the methods of moral education applied at SDIT Ummul Quro are

1. Exemplary Methods of an educator, such as being neat, polite, and always wearing syar'i clothes (according to Islamic law), and compulsory to take part in mentoring activities (Islamic studies) for work assessments.

2. The habituation method is more emphasized on students as recipient subjects, such as the habits that students do every morning at SDIT Ummul Quro, there are morning greetings (greetings in the early morning), always say greetings, greet each other, line up neatly before entering class. Before starting to learn to pray with khusyu, and continue with recitations,

3. Reward and funishment methods (reward and sanctions), in the form of reward and punishment

\section{F. ADVICE \\ ACKNOWLEDGMENTS}

AND

Given the urgency of the research results on Moral Education Methods at SD IT Ummul Quro, the authors provide some constructive suggestions for references to:

1. The government should further disseminate basic school moral education methods which are based on the Al-Qur'ān and al-Hadith, so that this method can be used as a reference in establishing educational policies to realize people who are faithful and pious, and have noble character as the realization of the formulation. national education goals.

2. Educational institutions, especially for elementary school education institutions, are expected to be able to implement the maximum moral education method which includes aspects of habituation, exemplary, advice and reward and funisment. 
3. Society to direct their children to always be motivated to have a noble character in all their activities, and avoid their children from despicable morals, so that the responsibility of education becomes a joint effort in the realization of a generation with noble character towards a dignified and respectful civilization like the morals of the Prophet. Saw.

It is with thanks al-Hamdul that the writing of this scientific paper can finally be completed. To all parties concerned, the author would like to thank you, hopefully what has been donated can make a charity field in yaumil qiyamah aamin.

\section{BIBLIOGRAPHY}

A’yuni, Muhammad Rijal Qurrota. (2016). Metode Pendidikan Yang Efektif Bagi Anak Menurut Al-Qur'an: Analisis Ayat-Ayat Al-Qur'an. Jurnal Atthulab, 1(2).

Agustina, Septia. (t.t.). Peran Sekolah Islam Terpadu Dalam Pembentukan Karakter Religius Siswa (Study Kasus di SDIT Islam Terpadu Permata Bunda Gedung Meneng Rajabasa Bandar Lampung). Jurnal Penelitian, n.d.

Asy'ari, M.Kholil. (2014). Metode Pendidikan Islam. Jurnal Qathruna, 1(1).

Fakhrurrazi. (2018). Potret Pendidikan Keluarga dalam Al-Qur'an (Tela'ah Q.S At-Tahrim [66]:6). Jurnal AtTibyan, 3(2).

Hasan, Zainol. (2017). Nilai-Nilai
Pendidikan Islam Pada Kisah Nabi Ibrahim. Jurnal Nuansa, 14(2).

Hawi, H.Akmal. (2015). Sistem Full Day School di Sekolah Dasar Islam Terpadu (SDIT) Studi Kasus di Izzuddin Palembang. Jurnal Istinbath, $\mathrm{XIV}(16)$.

Khoerunisa, Anna, and Nur Hidayat. (2017). Pembinaan Akhlak Siswa Melalui Metode Pembiasaan di MI Wahid Hasyim Yogyakarta. Jurnal Pendidikan Dasar Islam Al-Bidayah, 9(02).

Khomsiyatin. Metode Pendidikan Akhlak Pada Anak Usia Dini di Bustanul Athfal Aisyiyah Mangkujayan Ponorogo. Jurnal Educan, 2(1).

Lexy, Moleong J. (2017). Metodologi Penelitian Kualitatif. Bandung: Remaja Rosda Karya.

Manan, Syaeful. (2017). Pembinaan Akhlak Mulia Melalui Ketaladanan dan Pembiasaan. Jurnal Pendidikan Agama Islam-Ta'lim, 15(1).

Munirah. (2017). Akhlak dalam Perspektif Pendidikan Islam. Jurnal Pendidikan Dasar Islam, 4(2): 39-47.

Mustofa, Ali. (2019). Metode Keteladanan Perspektif Pendidikan Islam. CENDEKIA: Jurnal Studi Keislaman, 5)1). https://doi.org/ 10.37348/cendekia.v5i1.71.

Mustopa. (2014). Akhlak Mulia dalam Pandangan Masyarakat. Jurnal Pendidikan Islam, 8(2).

Nurjanah, Uul. (2017). Konsep Fitrah Manusia dan Relevansinya Terhadap Kreativitas Anak dalam Pendidikan Islam. Jurnal Ilmiah Tumbuh Kembang Anak Usia Dini, 2(1).

Nurmisdaramayani. (2017). Implementasi Ganjaran dan Hukuman dalam Proses Pembelajaran di MTs Al-Banna Pulau Banyak Kecamatan Tanjung Pura- 
Langkat. Jurnal Edu Riligia, 1(1).

Sitompul, Hafsah. (2016). Metode Keteladanan dan Pembiasaan dalam Pembentukan Sikap Pada Anak. Jurnal Darul 'Ilmi, 04(01).

Sugiyono. (2018). Metode Penelitian Kuantitatif, Kualitatif dan $R \& D$. Bandung: Alfabeta.

Ulwan, Abdullah Nashih. (2017).
Pendidikan Anak dalam Islam Jilid II. Jakarta: Pustaka Amani.

Yusra, Nelly. (2015). Implementasi Pendidikan Akhlak di Sekolah Dasar Islam Terpadu (SDIT) Al-Badr Kecamatan Bangkinang Kabupaten Kampar. Al-Hikmah: Jurnal Agama dan Ilmu Pengetahuan, 12(2): 217-32. https://doi.org/10.25299/alhikmah:jaip.2015.vol12(2).1508. 